\title{
CONCEPT OF DOWRY IN HINDU MARRIAGE SYSTEM: A STUDY
}

\author{
Dr. Sobia Khan \\ Assistant Professor \\ Department of Islamic Studies \\ The Govt. Sadiq College, Women University \\ Bahawalpur - Pakistan \\ sobiakausar.khan@gmail.com
}

\begin{abstract}
To demand Stridhana, formerly a woman's property, is now a boy's right. Her father freely gave it to her. It is part of a prenuptial agreement between two families, and even after the wedding, there is an expectation of more. Insufficient dowry has sparked protests due to the brutality of the dowry process and the deaths of females. Women's stridhan was a fundamental right. While the aristocracy had a lot of money, the impoverished women had to labour as maids or in handicrafts, agriculture and basket-making to support their families. The Manusmriti, a granth created by many between $200 B C$ and AD 200 and committed to writing in the twelfth century AD, had a significant impact on the position of Hindu women. According to the author, 'Brahma divided his body into two pieces, one for man and one for woman.' In other words, she was born equal. Where women are revered, there are gods, and where they are degraded, there is no hope. Manu, like the Jatakas, sees women as tempting, who blame males, and who should be avoided in isolation, much like in the Jatakas. No one expects males to gaze at women when they decorate themselves, dress, or rest. The daughters kid was not allowed to participate in rituals including mantras from infancy through puberty. Here, there is no mention of the guru's ashram's Brahmacharya time or the upnayana being done on girls.
\end{abstract}

Keywords: Hindu, Marriage, Dowry, Ashram's Brahmacharya, Katakas.

\section{Introduction}

Dower "Sanskrit is referred to as yautaka, or the material gifts of money or goods that confirm the union of those who are yuta or joined together in matrimony. In one form of 


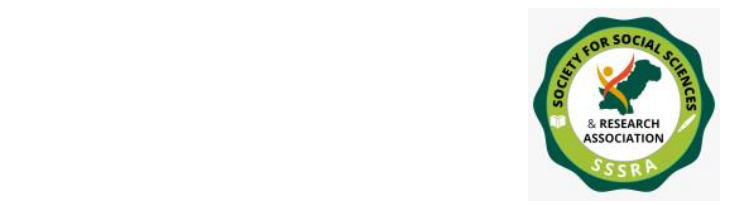

marriage in ancient India a girl was given away on her father receiving a bride price called sulka, which was a form of compensation to the girl's parents for the loss of their daughter. In another form the bride's father received a pair of kin. The custom fell into disuse by about the early middle ages, when it came to be regarded as disputable, but it is still practiced clandestinely where, for example a wealthy old man who desires a young bride will pay her father a large sum of money as a settlement for his daughter".

\section{Kanyadana}

"The gift of a virgin" is translated as "Kanyadaan." Bride's virginity was traditionally seen as a way to boost the esteem of the groom's parents when the father of the bride gave his daughter over to her husband's family. Poetic in its religious significance, the Kanyadaan ritual involves the bride and the groom accepting their spouses as manifestations of Vishnu and Lakshmi, respectively, or as a gift from the gods. It is also believed that the bride's parents' sins would be washed away if they give their daughter to Vishnu as a gift. While reading Vedic text, the father of the bride, or an older relative if the father is not present, lays the bride's right hand on her groom's hand. The Hastamelap, 'the linking of hands,' is the name given to this ritual. In exchange for the bride, the husband promises to assist her attain kama, dharma and artha. (Rao \& Nitya, 2012).

\section{According to Hinduism Encyclopedia}

\section{Kanyesulka}

The term "sulka" refers to the sale and purchase of a certain item. Medini cites varcid arthagrahanam as the translation here. The practise of kanyei-s-ulka means that a girl's social value (arhanari2 tat kurnarincim, Anu. 46.2) is paid for in terms of money to her family members, if sulka means price. In its previous use, the word 'price' connoted the selling and purchase of a woman. It's a vestige from the kanya-s'ulka ritual. The term "papa" in Sanskrit refers to both the condition that is set and the price (malya) that is requested. This is significant.

\section{Social Sciences Encyclopedia}

Both price and wealth are referred to here. Thus, the word "s'ulka" appears to be a misnomer, yet it must be used since there is no alternative word that conveys the idea of social interaction. There is a similar meaning to bride-wealth associated with the word mulya. Yaska wrote several hundred years after the Vedas were created, when their meaning was no longer understandable. ' As a result, he had no idea what the phrase 


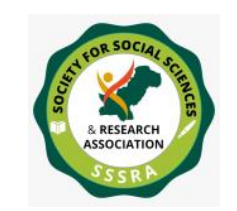

meant in Vedic times.

kanyd-s'ulka, because it is obtained from girl, is guilty of vikraya Manu subsequently (IX.98) suggests that even 8ildras not adopt the practise after condemning it for Brahmanas and Ksatriyas and recommending it for Vaigyas and 8udras. Even if they do follow it, his belief is that even they should give it up. As a man who grew up in a time where "women were not worthy of freedom," Manu naturally has such an extreme opinion. (Ahmad, 2010)

\section{Definition of 'Stridhan'}

Sanskrit strīdhana, from strī woman + dhana property - more at dhan

Women are called "stri," and property is known as "dhana," thus the name 'Stridhan. This is really a phrase and idea that has been handed down via the Hindu smritis through the years, but which has now infiltrated all kinds of unions, regardless of caste or religion. Stridhan is a marital property owned by a woman. Inheritances from her family, like as jewels, presents, and dowry materials, may be included. Items presented as wedding presents are historically regarded as the bride's property, or "stridhan," and signify her portion of her parents' riches. (Dalmia \& Lawrence, 2005).

\section{Types of Stridhan}

Stridhan's meaning has never been fully defined. Stridhan, according to the Smritikars, was defined as all of the gifts a woman got from her family members. Most of these presents were in the form of wearables, such as jewellery and other decorative items. Gifts from outsiders received during the wedding ceremony or the bridal procession also counted as Stridhan, as did gifts from family members. Stridhan suggested that the female had full ownership of property. During her maiden or widowhood, she was entitled to full rights of property alienation. However, the lady was bound by specific limits when it came to the disposal of such goods.

\section{Saudayaka}

1. Both her husband and her parents gave her these items as a token of their devotion for the lady in her life. The wife had complete alienation rights in relation to these presents. When a lady was in her twenties or thirties, she received gifts and bequests from her parents, siblings, and other family members.

2. When she received presents from her husband, she had no right to keep them unless he gave her permission. Included among these were the following: 


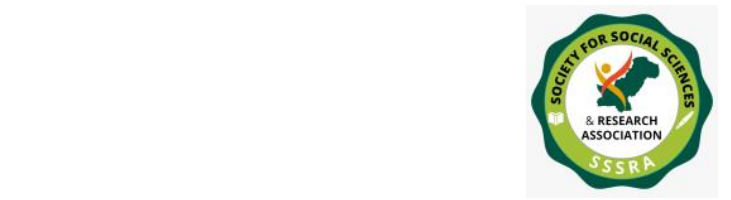

Property received as a gift or bequest from a stranger at the time of captivity. These were under the custody of the husband during his lifetime. Upon his death, it was taken over by the female.

Since women are always undervalued in marriage, the dowry system is founded only on the notion that monetary compensation is necessary to compensate for the unprofitable deal, not to offer stability for newlyweds and get them started on their new life together. Hindus have always feared the birth of daughters for this precise reason. Their single status is a disgrace to the family and a financial burden in the event of a marriage. (Biao, 2005)

\section{Per Thomas's Observations}

Liberal Hindus have slammed the dowry system as a form of oppression. In their view, the system assures that the Hindu girl will have the best husband money can buy. As a result of the 1961 law restricting the dowry system, opponents claim that the practise has only been replaced by private auctions of eligible bachelors instead of a public sale.

A social philosophy for the Hindu community in ancient times was also outlined in Smriti texts. The sectarian fire in India sparked the creation of new Smriti texts by other sects in the later years. They also compared deities and claimed that they were superior to those of other sects in their own writings. Satyanarayana Katha) even depicts deities as occasionally furious, spiteful, and authoritarian, and this is not an isolated incident. (Carroll, 1991)

\section{Historical Back Ground of Kanyadana/ Strithdan /Kanya Sulka}

Between 1000 and 500 B.C., royal families gave each other decorations, trousseau, animals, and slave ladies as wedding presents. But this was not a joint commitment. The primary donor family was chosen based on geographical, cultural, economic, or other factors.

Girls have been receiving stridhana and sulka from their male counterparts or their family since the 4th century B.C. The stridhana (literally, a woman's riches) included money for maintenance, jewellery, and apparel. However, later law-makers misinterpreted the sulka as brideprice. Both stridhana and sulka were utilised as prenuptial security deposits. If the marriage could not be performed owing to the boy's or 


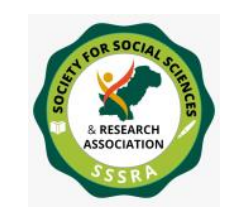

girl's fault, the offended party kept the stridhana and sulka. Strictly speaking, the stridhana passed to her offspring, spouse, or his family, and the sulka to her birth family.

Women who worked both before and after marriage were considered brideprice for a long time. However, women's dependent status increasingly falls from upper class and upper caste standards.

Concern arose when the Indian Parliament passed legislation in the 1950s outlawing polygamy among Hindus and providing females paternal property rights. In patriarchal civilizations, male heirs inherit private property, lineage, and ancestor respect. The dowry is intended to compensate the girl for giving up her property rights to marry her brother. Families go to considerable efforts to offer gifts for the daughter's new home, including jewellery, clothing, cash, and other essentials. These "gifts" belong to the husband's family, not the wife. The dowry amount depends on the boy's education and social position. The idea that a substantial dowry will elevate the girl's in-laws is false.

Cash is in high demand before and after marriage in merchant communities to buy expensive consumer goods like VCRs and colour televisions. Women's organisations in India are fighting to implement the country's dowry laws. There were 311 burning brides in Delhi in 1977 and 810 in 1982, illustrating the problem's extent. Of course, dowry wasn't always the sole consideration. Incompatibility, divorce humiliation, poverty, and a lack of female support networks may be to blame. The number is growing everywhere. (Leckie \& Charlton, 2011)

\section{General Characteristics of Hindu Marriage}

Prior to the 5th century B.C., previous Vedic scriptures give a consistent depiction of the state of marriage among the Hindu tribes depicted. With the exception of the elite, marriage in these tribes was a man-woman bond, indissoluble unless by death. While there is evidence of paying a bride price for a woman, there is also evidence of fathers or brothers donating dowries to guarantee the marriage of daughters or sisters. Marriage through capture is rare and limited to warriors.

The Pheras (circling the holy fire) and vowing to help one other to make the marriage a joyful and successful enterprise is the most important wedding rite. This is normally done with four, but seven pheras can be taken as well. The bride conducts the first two pheras and the husband the rest. 


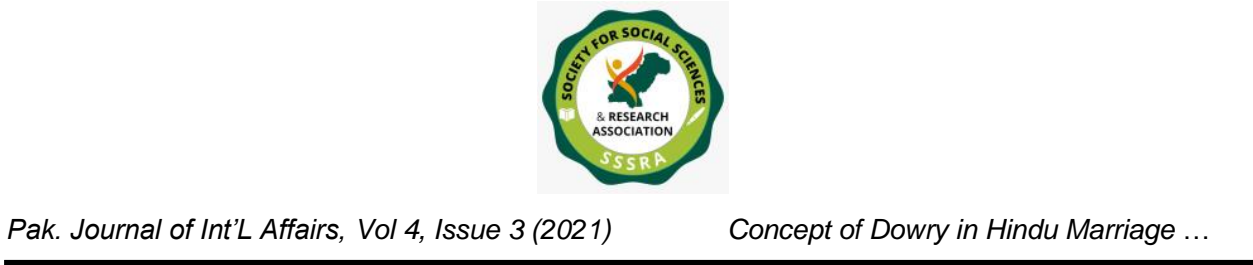

Kanya Daan: Towards the end of the wedding ritual, the bride's father conducts kanya daan, or delivering his daughter to the husband. The priest invites the bride's close relatives to present presents to her amidst shlokan mantra chanting and female singing. Gifts include milch cattle, decorations, and cash. (Ghosh \& Choudhuri, 2011)

\section{Sapatpadi (Seven Steps)}

Sapatpadi is the most significant Vedic wedding rite. Wedding vows are made here by taking seven steps together around the nuptial fire (Agni).

We must first nurture each other, then become stronger together, thirdly safeguard our riches, fourthly participate in our pleasures and sufferings, fifthly care for our children, sixthly be together for all time, and seventhly stay lifelong friends, perfect halves to build a perfect whole.

The foregoing verses teach us this. In Hinduism, a husband and wife have a lifetime alliance. Their biggest religion is loyalty to one other. Their prayers and worship should be similar for their spiritual liberation.

\section{Status of Indian Woman}

The boy and girl are intended to be students — vidyarthi — and hence dressed simply. The girl is dressed in a white sari, unstitched petticoat, and no jewellery. He wears a dhoti and shirt. In the North, the bride's maternal uncle provides these. The bride, bay, and parents fasted. If they become too weak to continue, they are fed fruits and milk.

Widowhood has undoubtedly earned the most compassion among Indian women, and the majority of reformers, men and women, have fought ceaselessly to improve their position. Allowing remarriage, training for employment, and societal acceptability have all been priorities. While the former is done in certain locations, the informants emphasised the latter because insisting on virginity in a wife mainly excludes the chance of remarriage. "Even smart guys avoid widows." "Remarried men of forty tend to marry virgins of around twenty." $\circ$ Y regarded teaching as the ideal answer for widows, "because they are unlikely to remarry anyhow." (Dogra, 1997)

\section{Dowry and Bride Price}

Bride price and dowry are phrases used in various cultures to describe payments given at the time of marriage. The bride or the newlyweds usually pay dowry. So bridal price and dowry are not mutually exclusive. However, in the twentieth century, the 


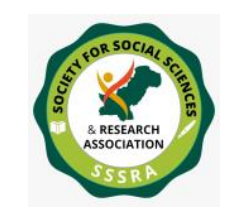

groom's family began to demand and receive dowry money (and not just to the bride or the wedded couple). This shows the term dowry refers to a groom's price, not a bride's price. Bride price and dowry do not have to be mutually exclusive. So a complicated set of criteria may regulate the kind and size of both payments.

Manu considers the first four marriages virtuous. These are aful. Manu says marriage should be conducted with father's approval. The trip is for a child's brain, so she has no option. That love and passion in marriage has been overlooked. Manu thinks fine kids. He promotes same-caste or group marriage. He opposes fairiage with erent stock. Indiscriminate decisions will not promote better offspring. If so, the family's cultural legacy must be weakened. Marriage is a mental link between husband and wife. Marriage unites two. And mutual fidelity must endure. They should be in one bondage tie, working together, thinking together, and performing responsibilities together. (Kishwar, 1993)

\section{Mahbahrata Ppproved Five Forms of Marriages According to Dowery}

The epic is Vedic thought. It is linked to the Upanishads and Manu. Only the colour is altered, heightened, and imaginative. The poet describes five marital systems. Brahma, Gandharva, Asura, Rakshasa.

In nut shells Before the marriage, the guardian of the lady analyses the bridegroom's character, education, social standing, and occupation. Prajpati is a custom when the guardians of the bride give money and property to the bridegroom before the wedding. Brahmans and Kshatriyas marry fairly.

Gandharva, where the bride and husband are chosen. Asura, when the bridegroom either buys her for money or tempts her family to marry her. Rakshasa When the bride's family refuses to marry her, the bride groom abducts her after torturing her family.

The poet thinks the first three systems are just. The other two are guilty. Only within their own caste are fair marriages permitted. But the poet has considerable leeway. Intercaste marriage is restricted by him. Brahmans may marry Kshatriyas and Vaishyas. Kshatriyas can wed Vaishyas. The higher three castes may take Sudra wives for fun only. Their offspring are guilty. And he's set the marriageable age for the bride and groom! In his opinion, the thirty-year-old bridegroom should marry the bride. In his opinion, a thirty-year-old guy should marry a ten-year-old bride. A twenty-year-old groom should marry a seven-year-old wife. As a result of the changing social hierarchies, it appears that certain deviations from Vedic and Manu's ideals occurred. 


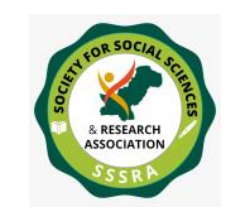

This is a fantastic lyrical skill of Vsasadeva. He is a brilliant socialist and a doer of justice. His acute understanding of this complex topic in line with the time is commendable.

The dower system was also used back then. This was not uncommon in Vedic times. It is linked to weddings. The poet saw it at Anusasan parvan. After Pandu married Kunti, the monarch Kuntobhoja lavishly rewarded him. In essence, this deed constitutes marital dowry. The epic has more of them. This is a dowry aspect. In another sense, it's a marriage tax.

In the Prajapati system, the tax is paid as part of the marriage contract. It does not validate the ultimate marriage. It's just a contract between the parties. If the father of the bride-to-be takes such a tax, he is obligated to reimburse it. The tax prayer would have full right on the future bride. If the prospective bridegroom is absent for a long time, the bride may marry another guy to have a child for the benefit of the tax payer. These are the primary points found in the Mahabharata on marriage and related topics.

Keny Sulka Post-Vedic Texts If sulka means price, then kanyei-s-ulka Prior to this, the word referred to the selling and buying of a girl's fortune. S'ulka looks to be a misnomer, yet it must be used because no other term implies social trade. The term mulya has the same meaning. As opposed to a predetermined gift ofs'atam atiratham, given to a girl regardless of her social status (thus her appearances were regarded rather than her merit). So the gift is a niyata-dana, not a price that fluctuates with the item's worth. Furthermore, he claims that the Smrti prohibits sale since it contradicts surti (s'rutismrtyor virodhe sati s'rutir baliyasi). Making kraya-vikraya allusions in the Vedic literature like dharmameitram, niyatarh danam should not obscure what is'self-evident' (svatah-pramänita). On the surface, sabara's interpretations of the Vedic text appear implausible. Though the practise was not common among the upper classes in his time. (Srinivasan, Padma, \& Lee, 2004)

\section{Difference between Dana and S'ulka}

Exorbitant sulka must have been taken and the whole transaction proceeded out of greed therefore amounted to selling a girl. His class disapproves of this conduct. Surtis allow just a restricted gift (dana, not s'ulka). Ergo, the Vedic text does not speak to safe. That 8abara derived a meaning fit for his period while the upper classes did not have it is shown by his interpretation.

In Dharmagastras, we notice a rapid shift in mindset. Because it is difficult to 


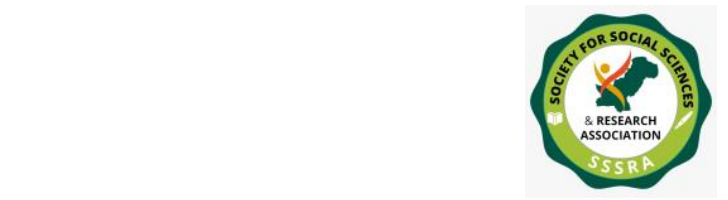

Pak. Journal of Int'L Affairs, Vol 4, Issue 3 (2021)

Concept of Dowry in Hindu Marriage ...

ascertain the chronology of Dharmagästras, we have attempted to investigate the key ages from a historical viewpoint. This investigation confirms the evolution of the practise throughout time. While the practise had a negative connotation in Vedic times, it has a positive connotation in the Dharmagftstras since it is not practised by the upper classes. As previously stated, when the practise is labelled as adharmya, it is solely from the perspective of the higher classes. The tradition remained among the Vaigyas and even during the Smrtis. It still exists among the poorer classes. (Rocca, $\mathrm{CH}$, Rathod, Falle, Pande, RP, \& Krishnan, 2009).

\section{Dowery Involve in Hindu Marriage Structure}

\section{Marriage by Purchase}

The Mahabharta (cxiii-9) mentions Pandu paying the Madra King with money, jewels, horses, elephants, decorations, etc. for his sister's hand. Manu approves four types of Brahma daiv, arsa, and prajapatya. To a priest conducting a rite for him, to a suitor giving oxen, and to the bridegroom proposing the marriage. As a result, the first and fourth forms indicate weddings by mutual consent and parental arrangement, while the second and third forms make it clear that the oxen were not intended as a price, but as a token of honour. The command refers to the tradition of providing the father in law hundred oxen with a waggon, and the Grhysutras of the Kathaka and Manava schools recognise a usage wherein the bride price was given in money to the father. Buy-in marriage. (Prasad, 1994)

\section{The Arsa and Asura forms of Marriage}

Giver and recipient engage in the gift and therefore in each other, which is a mystic force. The giver sets himself in relation to the receiver; the accepted gift frequently bonds. Offering means "giving part of oneself to a foreign entity, in order to form a solid link." In addition to the present, the receiver or buyer gains a part of the giver or seller's personality. It would be risky if he did not return the present and establish an exchange relationship. This is why most people strongly oppose the donation of a 'bride-price' as a vulgar business transaction.

In the previous and succeeding stanzas the author examines presents, sales, performances, etc. from the standpoint of honesty. Irreproachable (niravadya, Kulluka) is the first girl described in Stanza 204. Manu does not deny the reality of s'ulka-marriage, but prevents the man who aspires to follow the true dharma from engaging in such an affair. In VIII.204, he considers what people consider commerce or a delivery. As 


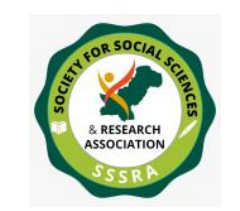

Pak. Journal of Int'L Affairs, Vol 4, Issue 3 (2021)

Concept of Dowry in Hindu Marriage ...

Kulluka correctly points out, the gift of the girl after accepting the s'ulka bears the character of a sale

The gandharva and asura marriages were regarded as Vaisya and Sudra.

The Vaisya and Sudra acknowledged the gandharva and asura marriage forms, with certain authorities recognising the paisacha. Today, even Vaisyas and Sudras acknowledge the asura or brahma marriage forms, which include the essence of the first four Smrtis.

These people do not acknowledge a kind of marriage that is important in the epic, the self-choice, in which a princess chooses her own suitor during a large gathering. Even when this formality was avoided, it is likely that the princess was steered by her father or brothers' desires, and that the decision was only nominally free. The Smrtis mention just one svayanivara: a daughter's right to seek her own spouse if her father does not find one for her; in this instance, the daughter loses all rights to her own family's ornaments, but the husband need not pay a bride price and may whisk her away.) (International Institute for Population Sciences and Population Council. 2010)

\section{Marriage by Capture in Rigveda}

In the Rigveda, we read about Vimada taking Purmitra's daughter, allegedly with her consent but against her father's wishes. The regular marriage was properly celebrated in the bride's father's house, and its ceremonial components are found in various IndoEuropean and non-Indo-European marriage rituals. There were many important and widespread customs, such as the solemn handing over of the bride by her father, tying of the bride and groom's right hands, recitation of Vedic formulae, including a speech by the bridegroom to the bride asserting their unity, the offering of libations in front of the fire, the threefold circumambulation of the fire, and finally taking the bride to her new home. Many of these practises are still observed today, as evidenced by later literature. (Vohra, 2003)

\section{Kenya-Sulka and the Position of Women in Society}

"Kanya-s'ulka is strongly linked to women's social standing, which is established by their participation in social production. 19 In communities where women engage in social production, kanyd-s'ulka is the husband and his tribe paying for a girl's basic services. So kanycis'ulka is an exchange of two kinds of wealth: money and the girl's vital services. To compensate the bride's family for her loss of services, the bridegroom paid a sum, according to Altekar. " In this view, kanyd-s'ulka is far from dishonourable, 


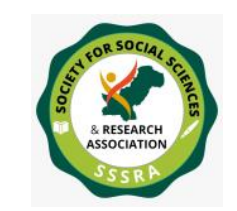

as it acknowledges the woman's equal and vital position in the household. For a girl and her family, giving her in marriage for nothing is shameful, adds Altekar. Sociologists dictate that to learn about our forefathers, we must study the current tribe behaviours."

We may also relate this to certain uncivilised societies. The prospective bridegroom works for the father-in-law for a while. It's a reward for depriving her father of his daughter's services. Later, money, land, or gold supplanted barter. The ancient Indian writings make no mention of this prehistoric activity. Someone had passed that stage during the recording time. It is mentioned in the Baudh $\mathrm{Dh} \mathrm{Su}$ 1.11.20.1, which asserts that äsura marriage is acceptable for the Vaigyas and Siidras, and why: aniyantritakalatra hi vais'yslidrä bhavanti. Women's utility in agriculture and labour gave them value and entitled their fathers to kanyu-s'ulka. At III, Manu appears to agree, forbidding Brahmanas and Ksatriyas from accepting kanyd-s'ulka, but allowing Vaigyas and Sildras to do so.

Taken by the Brähmana and Ksatriya females in Manu's day, it is a vikraya; by the Vaigya and gadra ladies, it is their worth and therefore not vikraya. Women's value, importance, and subsequent liberties are linked to their social productive usefulness. Less women were involved in social production as slaves (war prisoners) and private property became more common. As a result, women's services were no longer required because slaves provided inexpensive labour. So they lost their value and became a burden to the man who married them for a price. (Srinivasan, Padma, \& Lee, Gary, 2004)

\section{Factors behind Marriage Payments}

Many theories have been proposed to explain bridal price and dowry. One hypothesis describes dowry as a promoter bequest provided to daughters and ties it to women's inherited rights. Another theory relates marriage payment to women's economic value. Brides are valued in communities where women contribute to agriculture or other economic activities. Women who do not work are considered a financial responsibility and so bring a dowry. A third theory claims that marriage fees equalise demand and supply for brides and grooms. So when grooms are rare, brides pay dowries, and when brides are scarce, grooms give a bride price. Marriage and social relationships are linked in bride price ideas. So, for example, bride price is frequently recorded in communities with widespread polygamy (not just the wealthy), but dowry is virtually always observed in monogamous societies. Brides are supposed to marry into a higher caste or social group, whereas brides are expected to marry into a lower caste or social group. 


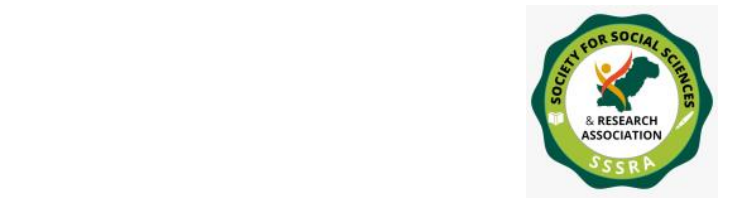

They are not mutually exclusive, and other factors may contribute to the decision of marriage payments in any community. Another point is that the removal of one sort of payment does not require the introduction of another. (Vohra, 2003)

\section{Dowry System and Law of Inheritance}

The dowry custom is quite old. The Vedas and other Hindu writings imply it. Matrimonial presents were common in the royal family. Ornaments and jewellery were the major focus of the shows. They used to gift slaves and horses along with decorations. Kunti, Draupadi, and Uttara are proof. As may be seen, this system was time tested. The system endured for millennia and is still in use today. It was recently forbidden by legislation. But I think we can all agree that the tradition lives on. This system can only last so long and so broadly if it has moral standards. Let us discover the underlying facts and the contributors' motives.

In Hinduism, boys and daughters are equal. Parents adore them as well. Sons live with their fathers after marriage, whereas daughters live with their husbands. Daughters had no claim to their father's wealth back then. Promoters of this custom undoubtedly thought it would fill a financial void. This led to the dowry system. So this custom had social and moral worth. And the purpose was good. So the dowry system must be good and moral. However, it must be recalled that it was a choice gesture from parents to their daughters. Its use was not compelled. But in today's world, it's a must. Unfair pressure on impoverished parents to provide dowry for daughter's marriage is certainly cruel. (Rocca, CH, Rathod, Falle, Pande, RP, \& Krishnan, 2009).

\section{Dowry in India}

During the era 1000-500 B.C., royal families gave each other jewels, trousseau, cattle, and slave females as wedding gifts. But it was not a shared obligation. Which family would be the main contributor depends on geographical, cultural, economic, and other variables at the time.

Since the 4th century B.C., females were expected to accept gifts and sulka from guys or their families. The stridhana (lit. a woman's riches) consisted of a certain quantity of food, jewellery, and clothing. Later lawmakers saw the sulka as brideprice. As a security deposit against premarital defents, stridehana and sulka. If the boy or girl could not be married, the offended party kept the stridhana and sulka. After the wife's death, the stridhana went to her children, husband, or his family, and the sulka to her natal family. 


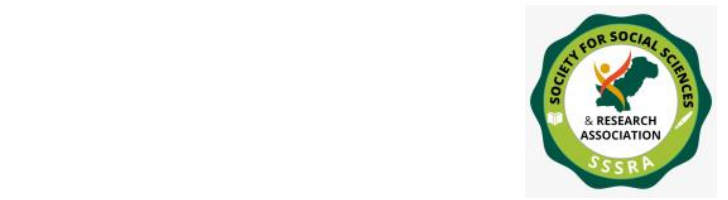

The nature of the marriage influenced a woman's full claim to her property. A husband had limited property rights in holy marriage but none in secular marriage. As a result, fewer secular weddings occur, while more sacred marriages occur, especially among the wealthy. As a result, the husband seized ownership of the wife's possessions.

The religious literature vehemently opposed "selling" a daughter for "bride price" and urged instead the "gift" of a female. "Gift" signified not just the girl's permanent move but also her non-employment. Thus, the male was excused from contributing anything to his potential bride before marriage, and her parents were solely responsible for her future.

The transition from bridepice to dowry happened between the fourth and second centuries A.D., with fundamental social changes. Expanded trade, commerce, mining, and other sectors increased social diviosion of labour. So the brahminical orthodoxy developed an intricate hereachical social framework following a brief period of heterodox religious unrest.

The victory of orthodoxy affected women's standing. The natural son inheriting private property and performing ancestor worship became a major social element. Women couldn't inherit or execute religious ceremonies. Widow marriage was discouraged, and previously permissible divorce was outlawed. The spouse became a deity and marriage became a rite for girls. Child marriage for females was preferred to ensure paternity. Married young, a woman had no access to school and was only capable of household duties. In place of these social losses, her stridhana rose by include any money and gifts obtained in connection with her marriage.

The issue arose when the Indian Parliament banned polygamy among Hindus in the 1950s and granted females parental property rights. In a patriarchal culture, male heirs inherit and concentrate private property, continue lineage, and worship ancestors. In this scenario, dowry is meant to recompense the girl for giving up her property claim in favour of her brother. Their generosity extends to the boy's family as well as to the daughter's new house. But the dowry belongs to the husband and his family, not the bride. The dowry depends on the boy's position and credentials. A large dowry is thought to strengthen the girl's position in family rules.

Consumer items like videocassette recorders (VCRs), colour televisions, and so on are in high demand before and after marriage. The Indian parliament has enacted further anti-dowry legislation, and women's groups are attempting to enforce it. However, the issue is so widespread that in 1977, Delhi alone had 311 occurrences of burning 


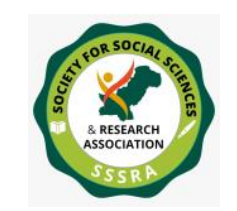

brides, and 810 in 1982. Of course, not every instance included dowry. Incompatibility, divorce stigma, economic and social uncertainty, and lack of female support systems may be contributing factors. In any case, the number is rising.

Greed, materialism, and a faster means to earn money are blamed for the rise in dowry. As long as dowry is seen as a moral or legal issue, it will be tied to her husband's. So she'd be the only owner, and her property would pass to her children or natal relatives. Women's groups are also pushing for useful gifts like income-generating assets instead of baubles and the like. Feminists argue that marriage is neither necessary nor inviolable. Worse, they believe, current beliefs should shift to promote gender equality. (Xaxa, 2004)

\section{Dowry Inflation and the Marriage Squeeze in India}

In the second part of the 20th century, dowries rose dramatically in India. Despite the dowry Prohibition Act (1961), which made the payment of dowries illegal, bride burning and dowry deaths grew increasingly widespread during this time period.

The phenomena of dowry inflation in India is puzzling given the extensive occurrence of female infanticide and female feticide in India throughout the twentieth century. So why should poor Indian women have to pay more and more for grooms? However, the form of marriage payments is governed by the ratio of marriable men and women. This ratio may be biased in favour of women, resulting in a positive dowry price even when the general sex ratio is skewed in favour of males. The marriage squeeze theory argues that population expansion in India in the 1930s explained dowry inflation. Here's the reasoning. With rapid population expansion, younger cohorts overwhelm older cohorts. A marriage squeeze on women occurs when older men marry younger women, leading the price of groom to rise. The Indian dowry inflation has also been explained by the norm of caste hyper gamy followed in some locations. The shifting economic worth of women and changing social structures in India at this period suggest to Sankritization emulation by lower castes of the higher caste practise of paying dowry. (Srinivasan, Padma, \& Lee, 2004)

\section{Position of Widows}

Women who were pregnant or had small children were not burnt alongside their husbands unless they were royal families, where policy probably overrode religious considerations.

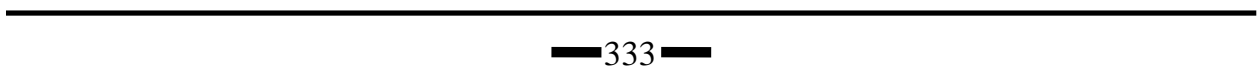




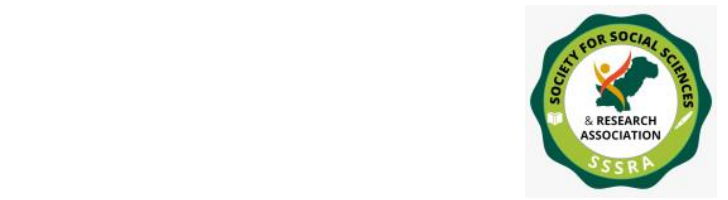

The Smrtis and present custom, notwithstanding reformers' attempts, sentence a widow to a life of fasting, devotions to her departed spouse, pilgrimages, and abstinence from any sort of luxury such as bed, decorations, etc. Act XV recognises her right to be heir to her spouse, but only if she remains unmarried. The severity of the regulation is best understood when considering how child marriage increases the number of widows.

In the Rigveda, the dead man's wife is taken in marriage by his brother, whether or not he previously had a wife. As a result of this natural interpretation of the burial chant, many men have two wives in the Punjab, where current use has kept much of historic tradition. In the Sutras, however, this practise is limited to giving permission to the deceased's brother or widow to carry on the deceased's race. His father's property was controlled by his mother or by his true father, to whose state he may ascend in some situations. The Vedas enable an impotent or ailing man to select someone to beget a son for him, and the epic regularly recognises this prerogative as being especially fitting for Brahmans. Contrary to popular belief, the tradition of appointment has been supplanted by a more primitive type of marriage with a brother's widow.

Wives could not remarry, forsake their sexuality, could not utter the names of other men, and had to live ascetic on fruits, roots, and flowers. They got their hair cropped, wore no jewellery, slept on rough surfaces, ate just once a day, and fasted twice a month. Their presence was cursed; they were barred from all feasts and festivities, and became unpaid drudges.

This harsh treatment has been significantly mitigated, yet many widows still endure it." A widow is an outcast. Previously a physical sati, she is now a psychological sati. She is still excluded from modern family celebrations. When a widow returns to her husband's house, she is a burden and treated like a servant. She gets a little pity, but she's typically blamed for her husband's death. Her security was tied to her spouse, and she isn't ready to be alone. She can't train for independence while her spouse is alive. She dares not bring up his mortality during his lifetime. 'You're thinking of my demise.' As a widow, she enjoys the customary Indian woman's protection. (Leckie \& Charlton, 2011)

\section{Status of Widow Property}

Unlike inherited property, the wife's stridhana was first referenced in the Arthasastra and Visnu. It comprised gifts from parents, sons, brothers, and kinsmen, the bridal price from her father, and the fine paid by her husband if she was demoted from her status as top wife to another. When she died, her property went to her unmarried daughters, or if she had no children, her forms of marriage, and her landed property went 


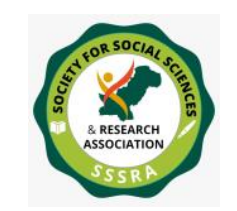

to her brothers. A commentary on contends that any property received by women in whatever fashion falls under that heading, and must respect the particular norms of devolution of stridhava proper. According to past evidence, a woman can only dispose of property that she inherited from her husband, acquired herself, or was given by outsiders with her husband's approval. Property rights and inheritance are controlled by religious community personal rules, which differ between Hindus and Muslims. We'll start with the laws governing widows' property rights and then look at how they work in practise.

Hindus distinguish between ancestral/joint family property and self-acquired property. The Dayabhaga and Mitakshara were two schools of law that governed ancestral property. The Mitakshara legislation ruled Bihar. A male joint family member had a birthright stake in ancestral property under Mitakshara law. A guy might request a share and divide it. When a guy died without requesting a split, Women had no right to inherit family property. They were only entitled to food, shelter, clothes, education, and marriage expenses from such property.

The Hindu Succession Act of 1956 changed several things. A Hindu guy might now give up his ancestral property stake. Intestate estates are split among the heirs. A predeceased son or predeceased daughter's successors include the widowed daughter-inlaw and the predeceased son's predeceased son's children. A Hindu male's self-acquired property might be willed away. If he died intestate, his property would be split evenly among his heirs. Despite their conceptions of property rights, the women had little actual influence over the land. What they could really do was dependent on a number.

A childless wife is less likely (and more difficult) to claim use rights over her husband's share of property, and use rights over her husband's lands, than a child-bearing widow with adult sons. (Kishwar, 1993)

\section{Code of Conduct for the Man of Jati or Race}

A man's behaviour in the four ashrams, daily regulations, and laws for the kings to follow were all part of the Manusmriti idea. The Manusmriti is not a treatise on women's rights. After all this, "Manu may be credited with portraying women as worthy of respect and protection as racial propagators. He plainly asserts that a society cannot grow without happy women, and no family can prosper with sad and cursed women. Women must maintain their virginity and dress pleasantly for their husbands in order to bear children, even if they do so out of wedlock. So they had to run the household and look after all family members and guests. They didn't offend each other at the wedding. They might keep their stridhan (parents or in-laws' money) and inherit property and 
fortune if unmarried or no male issues remained. Their sons were to care for them as widows. And their sons in old age, Manu said emphatically. This idea matched society's demands. Manusmriti, as this literature was most commonly referenced to clarify her viewpoint, unfortunately had a depressing effect on the plight of Indian women. In early mediaeval times, few women overcame this idea to pursue a career. (Ghosh \& Choudhuri, 2011)

\section{Conclusion/Recommendation}

The practise of dowry has transcended the boundaries of caste and has become widespread throughout society. Despite the fact that dowry is strictly prohibited by law. Dowry regulations should be vigorously enforced, and they should serve as a disincentive to the practise of dowry in general. Any family or individual found to be responsible for bride burning or beating shall be compensated in the same coin at a public event. The public would be discouraged from engaging in the practise of dowry if regulations were strictly enforced. NGOs and women's organisations should also try to improve the lives of those who have been victimised by this practise. Making the decision to marry outside of one's caste will also assist to discourage the practise of dowry. 


\section{References}

Ahmad, N. (2010). Female feticide in India. Issues in Law and Medicine, 26(1), 13-29

Biao, X. (2005). Gender, dowry and the migration system of Indian information technology professionals. Indian Journal of Gender Studies, 12, 357-380.

Bradley, T, \& Pallikadavth, S. (2012). The Dowry Problematic' What Has Changed In A Decade? Dowry and Women's Lives in Kerala. Inernational Development and Global Health. University of Portsmouth.

Carroll, Lucy. (1991). Daughter's Right of Inheritance in India: A Perspective on the Problem of Dowry. Modern Asian Studies, 25(4), 791-809.

Dalmia, S, \& Lawrence, PG. (2005). The institution of dowry in India: why it continues to prevail. Journal of Developing Areas, 38(2), 71-93. doi: http://www.jstor.org/stable/pdfplus/4192976.pdf?acceptTC=true

Dogra, Bharat. (1997). Burden of Dowry System. Economic and Political Weekly, $32(44 / 45), 2855$.

Ghosh, B, \& Choudhuri, T. (2011). Legal protection against domestic violence in India: scope and limitations. Journal of Family Violence, 26(4), 319-330.

International Institute for Population Sciences and Population Council. (2010). Youth in India: Situation and Needs 2006-2007. Mumbai: IIPS

Kishwar, M. (1993). Dowry calculations: daughter's rights in her parental family. MANUSHI.Sep-Oct; (78):7. , 78, 8-17.

Leckie, G, \& Charlton, C. (2011). runmlwin: Stata module for fitting multilevel models in the MLwiN software package

Prasad, BD. (1994). Dowry-related violence: a content analysis of news in selected newspapers. Journal of comparative family studies, 25(1), 71-89

Rao, Nitya. (2012). Male 'Providers' and Female 'Housewives': A Gendered Coperformance in Rural North India. Development and Change, 43(5), 10251048. doi: 
10.1111/j.1467-7660.2012.01789.x

Rocca, CH, Rathod, S, Falle, T, Pande, RP, \& Krishnan, S. (2009). Challenging assumptions about women's empowerment: social and economic resources and domestic violence among young married women in urban South India. International Journal of Epidemiology, 38(2), 577-585.

Srinivasan, Padma, \& Lee, Gary R. (2004). The dowry system in Northern India: Women's attitudes and social change. Journal of Marriage and Family, 66(5), 1108-1117.

Suran, L, Amin, S, Huq, L, \& Chowdury, K. (2004). Does dowry improve life for brides? A test of the bequest theory of dowry in rural Bangladesh. Policy Research Division

Working Papers No. 195

Vohra, S. (2003). The practice of dowry from the context of Hinduism. Critical Half, 1(1), 33-35.

Xaxa, Virginius. (2004). Women and Gender in the Study of Tribes in India. Indian Journal of Gender Studies, 11(3), 345-367. doi: 10.1177/097152150401100304 